\title{
Bioavailability of sediment-associated mercury to Hexagenia mayflies in a contaminated floodplain river
}

\author{
Teresa J. Naimo, James G. Wiener, W. Gregory Cope, and Nicolas S. Bloom
}

\begin{abstract}
We examined the bioavailability of mercury in sediments from the contaminated Sudbury River (Massachusetts, U.S.A.). Mayfly nymphs (Hexagenia) were exposed in four 21-day bioaccumulation tests to contaminated and reference sediments (treatments) from reservoirs, flowing reaches, palustrine wetlands, and a riverine lake. Mean total mercury $\left(\Sigma \mathrm{Hg}\right.$ ) ranged from 880 to $22059 \mathrm{ng} \cdot \mathrm{g}$ dry weight ${ }^{-1}$ in contaminated sediments and from $90 \mathrm{to} 272 \mathrm{ng} \cdot \mathrm{g}^{-1} \mathrm{in}$ reference sediments. Mean final concentrations of methyl mercury $(\mathrm{MeHg})$ in test water were greatest $\left(8-47 \mathrm{ng} \mathrm{Hg} \cdot \mathrm{L}^{-1}\right)$ in treatments with contaminated wetland sediments, which had mean $\Sigma \mathrm{Hg}$ ranging from 1200 to $2562 \mathrm{ng} \cdot \mathrm{g}^{-1}$. In mayflies, final mean concentrations of $\mathrm{MeHg}$ were highest in treatments with contaminated wetland sediments (122-183 ng $\left.\mathrm{Hg} \cdot \mathrm{g}^{-1}\right)$, intermediate in treatments with contaminated sediments from reservoirs, flowing reaches, and a riverine lake $\left(75-127 \mathrm{ng} \mathrm{Hg} \cdot \mathrm{g}^{-1}\right)$, and lowest in treatments with reference sediments (32-41 $\left.\mathrm{ng} \mathrm{Hg} \cdot \mathrm{g}^{-1}\right)$. We conclude that the potential entry of $\mathrm{MeHg}$ into the benthic food chain was greater in contaminated palustrine wetlands than in the contaminated reservoirs, which had the most contaminated sediments.
\end{abstract}

\begin{abstract}
Résumé : Nous avons étudié la biodisponibilité du mercure dans les sédiments d'un cours d'eau pollué des États-Unis (rivière Sudbury, au Massachusetts). Des nymphes d'éphémères (Hexagenia) ont été exposées, dans le cadre de quatre épreuves de bioaccumulation de 21 jours, à des sédiments de référence et à des sédiments contaminés provenant de réservoirs, de tronçons d'eau vive, de milieux humides palustres et d'un lac fluvial. La quantité moyenne de mercure total $(\Sigma \mathrm{Hg})$ était comprise entre 880 et $22059 \mathrm{ng} \cdot \mathrm{g}$ poids $\mathrm{sec}^{-1}$ dans les sédiments contaminés et entre 90 et $272 \mathrm{ng} \cdot \mathrm{g}^{-1}$ dans les sédiments de référence. La concentration moyenne finale de méthyl mercure $(\mathrm{MeHg})$ dans l'eau étudiée était au plus haut $\left(8-47 \mathrm{ng} \mathrm{Hg} \cdot \mathrm{L}^{-1}\right)$ dans les expériences sur des sédiments contaminés provenant de milieux humides, dont la $\Sigma \mathrm{Hg}$ moyenne était comprise entre 1200 et $2562 \mathrm{ng} \cdot \mathrm{g}^{-1}$. Chez les éphémères, la concentration moyenne finale de $\mathrm{MeHg}$ était au plus haut dans les expériences sur des sédiments contaminés de milieux humides (122-183 ng $\left.\mathrm{Hg} \cdot \mathrm{g}^{-1}\right)$, intermédiaire dans les expériences sur des sédiments contaminés provenant de réservoirs, de tronçons d'eau vive et d'un lac fluvial (75-127 $\left.\mathrm{ng} \mathrm{Hg} \cdot \mathrm{g}^{-1}\right)$ et au plus bas dans les expériences en présence de sédiments de référence (32-41 ng Hg.g $\left.{ }^{-1}\right)$. Nous concluons que la possibilité d'entrée du MeHg dans la chaîne alimentaire benthique était plus grande dans les milieux humides palustres contaminés que dans les réservoirs contaminés, qui pourtant renfermaient les sédiments les plus contaminés.
\end{abstract}

[Traduit par la Rédaction]

\section{Introduction}

The Sudbury River in eastern Massachusetts (U.S.A.) has been contaminated by chemical wastes originating from the Nyanza chemical waste dump site (Nyanza site), a former industrial complex in the town of Ashland. Large quantities of mercury, a toxic metal with no known essential biological function, were released to the environment at the Nyanza

Received June 20, 1997. Accepted May 6, 1999.

J14076

T.J. Naimo, ${ }^{1}$ J.G. Wiener, and W.G. Cope. ${ }^{2}$

U.S. Geological Survey, Biological Resources Division,

Upper Midwest Environmental Sciences Center,

2630 Fanta Reed Road, La Crosse, WI 54603, U.S.A.

N.S. Bloom. Frontier Geosciences, 414 Pontius Avenue North, Suite B, Seattle, WA 98109, U.S.A.

${ }^{1}$ Author to whom all correspondence should be addressed. e-mail: teresa_naimo@usgs.gov

${ }^{2}$ Present address: Department of Toxicology, North Carolina State University, Box 7633, Raleigh, NC 27695-7633, U.S.A. site (NUS Corporation 1992; Wiener and Shields 2000). The fine-grained sediments in downstream reaches of the Sudbury River now contain a substantial quantity of inorganic mercury (Colman et al. 1999; Frazier et al. 2000), posing a potential hazard to biota in the river and its adjoining wetlands. High concentrations of mercury were found in fish taken downstream from the Nyanza site (NUS Corporation 1992), but it was not known whether the mercury accumulating in fish and other biota was derived from contaminated sediments or from other inputs to the river.

Information on the bioavailability of mercury in contaminated sediments in the Sudbury River and its floodplain was needed to assess the potential entry of methyl mercury (MeHg) into aquatic food chains supporting fish and higher trophic levels. Potential sources of $\mathrm{MeHg}$ to riverine biota include methylation of inorganic mercury in flowing reaches, reservoirs, riverine lakes, and adjoining wetlands (St. Louis et al. 1994; Hurley et al. 1995; Krabbenhoft et al. 1995; Rudd 1995). MeHg may also enter the river in atmospheric deposition (Rudd 1995).

In the present study, the bioavailability of mercury in fine- 
grained, surficial sediments from the Sudbury River was assessed in bioaccumulation tests with burrowing mayfly nymphs (Hexagenia) experimentally exposed to sediments from the river basin. Hexagenia is a benthic detritivore common in many North American rivers, including the Sudbury River. Burrowing mayflies and other benthic invertebrates are potentially important in the trophic transfer of $\mathrm{MeHg}$ because of their significance in the diets of fish and certain waterfowl. Hexagenia nymphs select substrates with high organic and silt content, an association that increases their exposure to sediment-associated contaminants. Hexagenia nymphs have been widely used as test organisms in laboratory tests, including bioaccumulation tests with inorganic mercury and MeHg (Saouter et al. 1991, 1993; Odin et al. 1994, 1995). Burrowing mayflies readily bioaccumulate $\mathrm{MeHg}$ associated with ingested sediment and detritus (Saouter et al. 1991, 1993; Odin et al. 1994, 1995). Bioaccumulation tests with Hexagenia, therefore, provide an indirect measure of the production of $\mathrm{MeHg}$ in mercurycontaminated surficial sediments and of the potential entry (flux) of $\mathrm{MeHg}$ into the benthic food chain.

Our objectives were $(i)$ to determine if Hexagenia mayfly nymphs exposed to mercury-contaminated surficial sediment from the Sudbury River accumulate MeHg, (ii) to determine if the accumulation of $\mathrm{MeHg}$ in mayflies is related to total mercury $(\Sigma \mathrm{Hg})$ concentration in sediment, and (iii) to assess which contaminated areas on the Sudbury River have the greatest potential for $\mathrm{MeHg}$ transfer from sediments into the benthic food chain.

\section{Methods}

\section{Experimental approach}

Four 21-day bioaccumulation tests were conducted with nymphs of Hexagenia experimentally exposed in the laboratory to sediments from the river basin. In 1994, bioaccumulation tests were conducted with sediments sampled from impoundments, flowing reaches, and a riverine lake during July (test 1) and September (test 2). In 1995, the bioaccumulation tests focused on wetland areas within the river floodplain, with sediments obtained in May (test 3) and September (test 4).

Microbial methylating activity in aquatic sediments follows an annual cycle that is closely linked to temperature, with peak $\mathrm{MeHg}$ production occurring during the warmest months (Ramlal et al. 1993). Our sediment sampling was done in May, July, and September, months of active $\mathrm{MeHg}$ production (Ramlal et al. 1993). Each bioaccumulation test employed a randomized block experimental design; tests 1 and 2 included six replicates of six sediment treatments, whereas tests 3 and 4 had nine replicates of four sediment treatments.

\section{Test sediments}

Sediments for the four tests were obtained from a total of nine study areas, with sediments from a given study area representing a treatment in our tests. In tests 1 and 2, sediments were obtained from four depositional areas and two free-flowing reaches in the Sudbury River basin (Fig. 1). Three of the depositional areas (Reservoir 1 (49 ha), Reservoir 2 (47 ha), and Fairhaven Bay (27 ha)) were contaminated areas that spanned the mercury contamination gradient attributed to the Nyanza site (NUS Corporation 1992). The fourth depositional area, the Whitehall Reservoir (233 ha), was a reference area that had not been directly contaminated by wastes from the Nyanza site. The two free-flowing reaches included one contaminated site (within the Great Meadows National Wildlife Refuge) and one upstream reference site that had not been directly contaminated by wastes from the Nyanza site.

Test sediments for tests 3 and 4 were obtained from four study areas, including two contaminated wetlands (both containing mercury from the Nyanza site), one reference wetland (Hop Brook wetland, not measurably contaminated by mercury from the Nyanza site), and one contaminated depositional area (Fairhaven Bay) (Fig. 1). Sediments from Fairhaven Bay were included in all four tests to facilitate comparison of test results between years. About $8 \%$ of the $427-\mathrm{km}^{2}$ Sudbury River watershed is covered by nonforested wetlands (NUS Corporation 1992). In particular, the reach about $20-35 \mathrm{~km}$ downstream from the Nyanza site contains an extensive floodplain and associated palustrine wetlands, lying within the $12-\mathrm{km}^{2}$ Great Meadows National Wildlife Refuge. These wetlands have been classified as palustrine wetlands with scrub-shrub and persistent, emergent herbaceous plants (Harris 1996).

Within each area, sediment was obtained from randomly selected sampling sites, identified by latitude and longitude coordinates. The spatial randomization of sampling allowed extrapolation of test data from the sampled sites to the soft sediments within a defined study area. When sampling in wetland reaches, we first located the randomly selected position in the main channel of the stream and then randomly selected a sampling site in the adjoining floodplain within $10 \mathrm{~m}$ (in $1-\mathrm{m}$ increments) of either the left or right stream bank.

Surficial sediments (uppermost 4-6 cm) for tests 1 and 2 were obtained with a Van Veen sampler, and sediments for test 3 were taken with an Ekman grab sampler (American Society for Testing and Materials 1992). During test 4, sediments in the three wetland areas were exposed due to drought-associated low water levels, and sampling of wetland sediments was done with a stainless steel spatula. In Fairhaven Bay, sediments for test 4 were taken with an Ekman sampler. Sediment for all tests was passed on site through a 2-mm Nalgene ${ }^{\circledR}$ sieve. Each sample was placed into a 1.9-L Nalgene ${ }^{\circledR}$ container with a screw top, held on ice in the field, and later stored at $10 \pm 5^{\circ} \mathrm{C}$ for a maximum of 24 days before beginning a bioaccumulation test.

Test sediments were analyzed for texture (sieve-pipet method; Guy 1969; Plumb 1981) and for volatile matter content (loss on ignition at $550^{\circ} \mathrm{C}$ ), a surrogate for organic matter content. Two textural groups were delineated, sand $(62-2000 \mu \mathrm{m})$ and silt plus clay $(<62 \mu \mathrm{m})$. During tests 1 and 2 , the physical characteristics of test sediment varied significantly among treatments (Table 1$)$. In particular, sediment from the Whitehall Reservoir had greater volatile matter content (about 60\%) than sediment from the other treatments (range 14-25\%). Sediments from five of the six study areas in tests 1 and 2 were primarily silt and clay (Table 1). The physical characteristics of sediments in tests 3 and 4 were less variable than those in tests 1 and 2 (Table 1). The mean textural composition of sediments from the Hop Brook wetland treatment differed from the that of other treatments in test 3 but not in test 4 (Table 1).

\section{Bioaccumulation tests}

The experimental unit in each 21-day bioaccumulation test was a 4-L glass beaker containing $725 \mathrm{~mL}$ of wet sediment from a given sampling site and $2900 \mathrm{~mL}$ of test water, providing a 4:1 $(\mathrm{v} / \mathrm{v})$ water to sediment ratio. During the allocation of test sediment to each beaker, a sample ( $>10 \mathrm{~g}$ wet weight) of the sediment added was placed into a $125-\mathrm{mL}$ Nalgene ${ }^{\circledR}$ container. Samples of test sediment were stored in a freezer at $-15^{\circ} \mathrm{C}$ or colder until analyzed for $\Sigma \mathrm{Hg}$.

Each beaker was covered with a 20 -cm-diameter watch glass to reduce evaporation of test water. The 36 experimental units in each test were held within two 900-L water baths. A temperature of 
Fig. 1. Map of the Sudbury River basin showing the areas from which test sediments were taken.

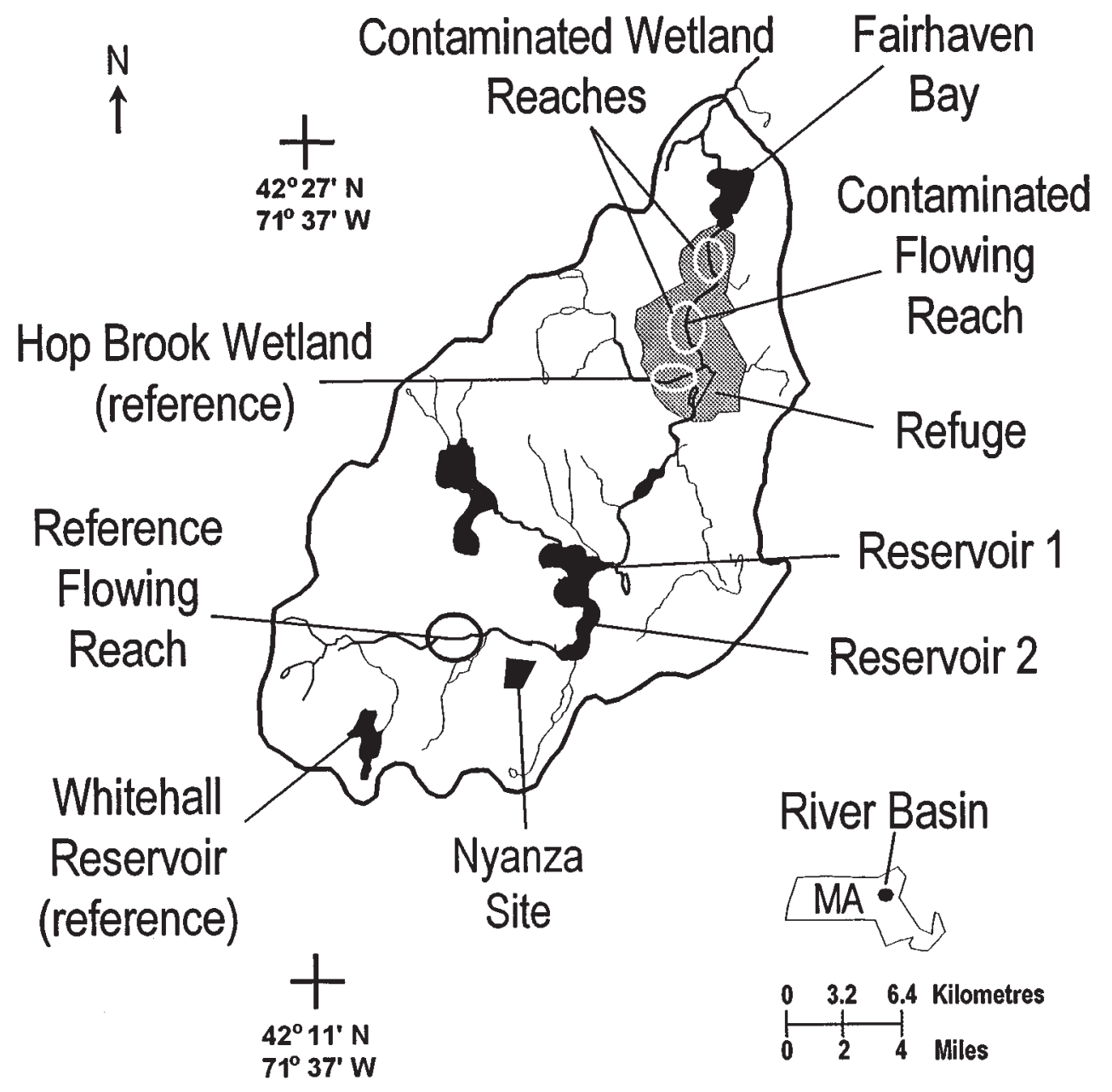

$20 \pm 2^{\circ} \mathrm{C}$ was maintained by a recirculation pump. Photoperiod was $16 \mathrm{~h}$ light : $8 \mathrm{~h}$ dark.

The overlying test water was soft, similar in hardness and $\mathrm{pH}$ to water from the Sudbury River. The test water was prepared by adding $36 \mathrm{mg} \mathrm{NaHCO} \cdot \mathrm{L}^{-1}, 7.5 \mathrm{mg} \mathrm{CaSO} \cdot \mathrm{L}^{-1}, 7.5 \mathrm{mg} \mathrm{MgSO}_{4} \cdot \mathrm{L}^{-1}$, and $0.009 \mathrm{~mL} 36 \mathrm{~N} \mathrm{H}_{2} \mathrm{SO}_{4} \cdot \mathrm{L}^{-1}$ to deionized water. During the four tests, the test water before sediment addition had a mean $\mathrm{pH}$ of 6.9 , a mean conductivity of $234 \mu \mathrm{S} \cdot \mathrm{cm}^{-1}$, a mean total alkalinity of $29.1 \mathrm{mg} \mathrm{CaCO} \cdot \mathrm{L}^{-1}$, and a mean total hardness of $34.9 \mathrm{mg}$ $\mathrm{CaCO}_{3} \cdot \mathrm{L}^{-1}$. During each test, the overlying water in each beaker was gently aerated to maintain sufficient dissolved oxygen $\left(>5 \mathrm{mg} \cdot \mathrm{L}^{-1}\right)$ for mayflies. Gaseous mercury $\left(\mathrm{Hg}^{0}\right)$ was removed from the air supply with two gold-coated quartz sand traps (Fitzgerald et al. 1991) placed in series in the air line delivering air to all beakers.

Hexagenia nymphs (almost entirely Hexagenia bilineata) were obtained with a Ponar dredge within 1 day before the start of each bioaccumulation test from Pool 8 of the Upper Mississippi River, an area with low $\mathrm{\Sigma Hg}$ concentrations in both sediment and resident Hexagenia (Beauvais et al. 1995). The mean initial (day 0) concentrations $\left( \pm 1 \mathrm{SE}\right.$ ) of $\Sigma \mathrm{Hg}$ and $\mathrm{MeHg}$ were $81 \pm 8 \mathrm{ng} \cdot \mathrm{g}$ dry weight ${ }^{-1}$ and $28 \pm 10 \mathrm{ng} \mathrm{Hg} \cdot \mathrm{g}^{-1}$, respectively, based on analysis of three composite samples of 10 whole mayflies per bioaccumulation test.

Each mayfly was measured (total length) and transferred into a beaker with a spoon-shaped piece of $\mathrm{Nitex}^{\circledR}$ mesh attached to a glass rod. Fifteen nymphs, ranging from 10 to $19 \mathrm{~mm}$ in total length, were randomly allocated to each beaker 7-10 days after the test sediment and water had been placed into the beaker. Day 0 of a given test was defined as the day on which mayflies were introduced into the beakers.

On day 21 of each test, about $100 \mathrm{~mL}$ of overlying water, to be analyzed for $\mathrm{MeHg}$, was taken from each beaker by immersion of a 125 -mL Teflon ${ }^{\circledR}$-coated bottle. Water samples were stored at $-15^{\circ} \mathrm{C}$ or colder until analyzed. Mayflies in each beaker were separated from the test sediment by passing the sediment through a 2-mm Nalgene ${ }^{\circledR}$ sieve. Mayflies retained on the sieve were removed with forceps, counted, and measured. Ten nymphs from each beaker were placed into a single $125-\mathrm{mL}$ Nalgene ${ }^{\circledR}$ container to yield one composite sample to be analyzed for $\mathrm{\Sigma Hg}$ and $\mathrm{MeHg}$; these samples were stored at $-15^{\circ} \mathrm{C}$ or colder until analyzed. We were interested in the trophic transfer of $\mathrm{MeHg}$ from sediments into the benthic food chain; therefore, we did not allow mayflies to depurate their gut contents before analysis (Hare et al. 1989).

\section{Test water}

The temperature of the overlying water, measured daily in situ, ranged from 19.5 to $20.8^{\circ} \mathrm{C}$ and did not vary among treatments in any of the four tests. The mean concentrations of dissolved oxygen, measured daily in situ, did not vary among treatments in test 1 or 3 but varied slightly in test 2 (from 7.5 to $7.9 \mathrm{mg} \cdot \mathrm{L}^{-1}$ ) and in test 4 (from 7.5 to $7.7 \mathrm{mg} \cdot \mathrm{L}^{-1}$ ). Although the mean $\mathrm{pH}$, measured daily in situ, in the overlying water varied significantly among treatments in all four tests (Table 1), the range in mean $\mathrm{pH}$ was $0.6 \mathrm{pH}$ unit or less in all but test 4 , in which mean $\mathrm{pH}$ ranged from 5.9 in the northern contaminated wetland treatment to 7.2 in the Fairhaven Bay treatment. On day 21 of each test, a water sample was 
Table 1. Mean ( $\pm 1 \mathrm{SE}$ ) values for selected characteristics of test sediment and test water to which Hexagenia mayflies were exposed in four bioaccumulation tests.

\begin{tabular}{|c|c|c|c|c|c|}
\hline \multirow[b]{2}{*}{ Treatment } & \multicolumn{2}{|l|}{ Test sediment } & \multicolumn{3}{|c|}{ Test water } \\
\hline & $\begin{array}{l}\text { Volatile matter } \\
(\%)\end{array}$ & $\begin{array}{l}\text { Silt plus clay } \\
\text { content }(\%)\end{array}$ & $\mathrm{pH}$ & $\begin{array}{l}\text { Conductivity } \\
\left(\mu \mathrm{S} \cdot \mathrm{cm}^{-1}\right)\end{array}$ & $\begin{array}{l}\text { Hardness (mg } \\
\left.\mathrm{CaCO}_{3} \cdot \mathrm{L}^{-1}\right)\end{array}$ \\
\hline \multicolumn{6}{|l|}{ Test 1 (July 1994 sediments) } \\
\hline Whitehall Reservoir & $58.0 \pm 1.5 a$ & $79 \pm 3 a b$ & $6.88 a$ & $143 a$ & $11.6 a$ \\
\hline Reference flowing reach & $16.8 \pm 3.0 b c$ & $37 \pm 6 c$ & $7.25 b$ & $215 b$ & $33.9 b$ \\
\hline Reservoir 2 & $15.8 \pm 1.7 c$ & $78 \pm 6 a b$ & $7.16 d$ & $237 b$ & $33.5 b$ \\
\hline Reservoir 1 & $13.6 \pm 1.6 c$ & $76 \pm 6 a b$ & $6.91 a$ & $254 b$ & $43.7 b$ \\
\hline Contaminated flowing reach & $17.7 \pm 2.5 b c$ & $57 \pm 9 b c$ & $7.37 c$ & $230 b$ & $42.6 b$ \\
\hline Fairhaven Bay & $24.7 \pm 1.2 b$ & $84 \pm 4 a$ & $7.24 b d$ & $211 b$ & $36.9 b$ \\
\hline \multicolumn{6}{|l|}{ Test 2 (September 1994 sediments) } \\
\hline Whitehall Reservoir & $62.2 \pm 5.2 a$ & $77 \pm 4 a$ & $6.99 a$ & $112 a$ & $10.3 a$ \\
\hline Reference flowing reach & $15.7 \pm 3.8 b$ & $50 \pm 4 b$ & $7.21 b$ & $195 b$ & $37.2 b$ \\
\hline Reservoir 2 & $16.6 \pm 1.2 b$ & $86 \pm 5 a$ & $6.91 e$ & $197 b$ & $28.6 b$ \\
\hline Reservoir 1 & $14.9 \pm 1.5 b$ & $83 \pm 5 a$ & $7.07 d$ & $197 b$ & $30.3 b$ \\
\hline Contaminated flowing reach & $20.8 \pm 1.2 b$ & $82 \pm 2 a$ & $7.28 c$ & $200 b$ & $42.4 b$ \\
\hline Fairhaven Bay & $18.4 \pm 2.3 b$ & $66 \pm 11 a b$ & $7.15 b$ & $180 \mathrm{~b}$ & $34.9 b$ \\
\hline \multicolumn{6}{|l|}{ Test 3 (May 1995 sediments) } \\
\hline Hop Brook wetland (reference) & $33.1 \pm 3.2 a$ & $78 \pm 3 a$ & $7.19 a$ & $148 a b$ & $26.4 a$ \\
\hline Southern contaminated wetland & $25.4 \pm 0.5 b$ & $89 \pm 1 b$ & $6.84 d$ & $126 c$ & $16.7 b$ \\
\hline Northern contaminated wetland & $27.2 \pm 1.6 a b$ & $90 \pm 1 b$ & $6.62 c$ & $108 c$ & $13.1 b$ \\
\hline Fairhaven Bay & $25.0 \pm 0.9 b$ & $86 \pm 1 b$ & $6.94 b$ & $177 b$ & $40.0 a$ \\
\hline \multicolumn{6}{|l|}{ Test 4 (September 1995 sediments) } \\
\hline Hop Brook wetland (reference) & $36.1 \pm 3.5 a$ & $80 \pm 5$ & $6.83 a$ & $329 a$ & 78.5 \\
\hline Southern contaminated wetland & $26.2 \pm 1.7 a b$ & $90 \pm 1$ & $6.50 d$ & $214 a c$ & 37.9 \\
\hline Northern contaminated wetland & $27.2 \pm 2.4 a b$ & $91 \pm 1$ & $5.93 c$ & $301 a c$ & 41.0 \\
\hline Fairhaven Bay & $21.7 \pm 3.5 b$ & $63 \pm 10$ & $7.18 b$ & $201 b c$ & 48.0 \\
\hline
\end{tabular}

Note: Means for a given variable and test that are not accompanied by a common letter were significantly different (Tukey's HSD procedure, $\alpha=0.05$ ). Treatments (sediment source) for each test are listed in longitudinal sequence from upstream to downstream.

taken from each beaker and analyzed for hardness, alkalinity, and conductivity. In tests 1 and 2, conductivity and hardness in the Whitehall Reservoir treatment were significantly lower than in the other five treatments, which did not differ. Conductivity also varied among treatments in tests 3 and 4 (Table 1). Mean alkalinity varied significantly among treatments in all four tests, with means for individual treatments ranging from 12 to $58 \mathrm{mg} \mathrm{CaCO}_{3} \cdot \mathrm{L}^{-1}$. Total ammonia nitrogen and un-ionized ammonia nitrogen, determined in water from one randomly selected beaker from each treatment, ranged from 0.05 to $1.20 \mathrm{mg} \cdot \mathrm{L}^{-1}$ and from 0.2 to $5.2 \mu \mathrm{g} \cdot \mathrm{L}^{-1}$, respectively, in the tests.

\section{Diet and ration}

To supply organic carbon to support microbial activity, each beaker was provided with dried, finely ground leaves of submersed aquatic plants. In tests 1 and 2, we used wild celery (Vallisneria americana) from Lake Onalaska (Pool 7, Upper Mississippi River) as a source of organic carbon. Curly pondweed (Potamogeton crispus) was used in tests 3 and 4 because wild celery was not yet available when test 3 was initiated. Fresh leaves were dried at $104^{\circ} \mathrm{C}$ for $72 \pm 12 \mathrm{~h}$, ground to a fine homogenate with a mortar and pestle, and stored in Nalgene ${ }^{\circledR}$ bottles in a desiccator. Beginning 2-3 days before day 0 of a test, $193 \pm 5 \mathrm{mg}$ dry weight of curly pondweed or $228 \pm 5 \mathrm{mg}$ dry weight of wild celery was added to each beaker every third day. These rates of wild celery and curly pondweed addition equated to a mean daily loading rate of organic carbon of about $100 \mathrm{mmol}$ per square metre of sediment surface in our beakers, a typical value for mesotrophic freshwater ecosystems (C.A. Kelly, Department of Microbiology, University of Manitoba, Winnipeg, MB R3T 2N2, Canada, and J.W.M. Rudd,
Department of Fisheries and Oceans, Freshwater Institute, 501 University Crescent, Winnipeg, MB R3T 2N6, Canada, personal communication). Concentrations of $\mathrm{MeHg}$ in a subsample of the plant homogenate were 5.1, 1.1, 5.3, and $4.2 \mathrm{ng} \mathrm{Hg} \cdot \mathrm{g}$ dry weight ${ }^{-1}$ in tests $1,2,3$, and 4 , respectively.

During test 3 , we evaluated the potential effect of the change in plant species on test results by placing sediment from a given site into two separate beakers and adding pondweed to one beaker and wild celery to the other. This evaluation was done with sediments from one sampling site in each of two sediment treatments (a contaminated wetland and a riverine lake). Test results were not measurably affected by the difference in plant species used as a source of carbon. At the end of test 3, the $\mathrm{MeHg}$ concentration in overlying water from beakers with sediment from the contaminated wetland was $11.8 \mathrm{ng} \mathrm{Hg} \cdot \mathrm{L}^{-1}$ in the beaker provided wild celery and $13.8 \mathrm{ng} \mathrm{Hg} \cdot \mathrm{L}^{-1}$ in the beaker provided curly pondweed. The $\mathrm{MeHg}$ concentration in overlying water from beakers with sediment from the riverine lake was $0.7 \mathrm{ng} \mathrm{Hg} \cdot \mathrm{L}^{-1}$ in the beaker provided wild celery and $1.0 \mathrm{ng} \mathrm{Hg} \cdot \mathrm{L}^{-1}$ in the beaker provided curly pondweed.

\section{Mercury determinations}

For determinations of $\Sigma \mathrm{Hg}, 1.0 \mathrm{-g}$ samples of sediment and $0.1 \mathrm{-g}$ aliquots of the mayfly composites were digested in refluxing 7:3 $\mathrm{HNO}_{3}-\mathrm{H}_{2} \mathrm{SO}_{4}$ (Bloom and Crecelius 1987) and analyzed by $\mathrm{SnCl}_{2}$ reduction, dual gold amalgamation, and atomic fluorescence detection (Bloom and Crecelius 1983; Bloom and Fitzgerald 1988). For determination of $\mathrm{MeHg}$ in mayflies, 0.1-g samples were digested in $25 \% \mathrm{KOH}$ in methanol (Bloom 1989, 1992), and aliquots were analyzed by aqueous-phase ethylation (Bloom 1989), carbotrap collection, isothermal gas chromatographic separation (Liang et al. 
1994), and atomic fluorescence detection. Water samples (35 mL) were pre-separated by distillation (Horvat et al. 1993; Bloom and Von Der Geest 1995) before analysis for $\mathrm{MeHg}$ by the ethylation technique.

An aliquot of each sample of sediment and mayflies was analyzed for percent dry solids. The dry fraction was determined gravimetrically after drying overnight in an oven at $105 \pm 5^{\circ} \mathrm{C}$. Mercury concentrations in sediment and mayflies were reported on a dry weight basis.

\section{Quality assurance}

All samples were handled according to chain-of-custody procedures. All glassware, plasticware, and tubing used in the bioaccumulation tests was acid washed $\left(10 \% \mathrm{HNO}_{3}\right.$ for $\left.24 \mathrm{~h}\right)$ before use. Precision (relative standard deviation) during volatile matter and particle size determinations on sediment and during determinations of total alkalinity, total hardness, and conductivity in water (day 21) was estimated from triplicate analyses of $10 \%$ or more of the samples analyzed. Relative standard deviations were $0-15 \%$ for total alkalinity, $0-11 \%$ for total hardness, $0-3 \%$ for conductivity, $0.1-5 \%$ for volatile matter, $2-44 \%$ for percent sand, and $0.3-1 \%$ for percent silt plus clay (data from all four bioaccumulation tests combined).

During the determination of $\mathrm{SHg}$ and $\mathrm{MeHg}$ in mayflies, water, and sediment, we analyzed one method blank, appropriate certified reference materials, analytical duplicates, and blind duplicates per 20 samples analyzed. Concentrations of $\mathrm{\Sigma Hg}$ and $\mathrm{MeHg}$ in certified reference materials (dogfish muscle (DORM-2) and marine sediment (PACS-1)) were within the certified ranges, whereas our mean concentration of $78.7 \pm 2.9 \mathrm{ng} \cdot \mathrm{g}$ dry weight ${ }^{-1}$ for $\Sigma \mathrm{Hg}$ in estuarine sediment (NIST-1646) slightly exceeded the certified range of $63 \pm 11 \mathrm{ng} \cdot \mathrm{g}$ dry weight ${ }^{-1}$. Estimated method detection limits were $0.053 \mathrm{ng} \mathrm{Hg} \cdot \mathrm{L}^{-1}$ for $\mathrm{MeHg}$ in water, $0.44 \mathrm{ng} \cdot \mathrm{g}$ wet weight $^{-1}$ for $\Sigma \mathrm{Hg}$ in sediment, $3.5 \mathrm{ng} \mathrm{Hg} \cdot \mathrm{g}$ wet weight ${ }^{-1}$ for $\mathrm{MeHg}$ in mayflies, and $1.8 \mathrm{ng} \cdot \mathrm{g}$ wet weight ${ }^{-1}$ for $\mathrm{\Sigma Hg}$ in mayflies. Mean $( \pm 1$ SD) matrix-spike percent recoveries were $97 \pm 13$ for $\mathrm{MeHg}$ in water, $105 \pm 14$ for $\Sigma \mathrm{Hg}$ in sediment, $109 \pm 15$ for $\mathrm{MeHg}$ in mayflies, and $97 \pm 11$ for $\Sigma \mathrm{Hg}$ in mayflies. The mean relative percent difference between duplicate samples ranged from 4 to $25 \%$.

\section{Statistical analyses}

Mercury concentrations in sediment, water, and mayflies were tested for normality and homogeneity of variance. The data were not normally distributed and had inequality of variances; thus, all subsequent analyses were performed on rank-transformed data. For each bioaccumulation test, variation in mean concentrations of $\mathrm{\Sigma Hg}$ or $\mathrm{MeHg}$ in sediment, mayflies, and water among treatments was compared by one-way analysis of variance. Tukey's HSD multiple range test was performed to compare treatment means when the analysis of variance was significant. The mean net $\mathrm{MeHg}$ accumulation (nanograms per mayfly) in each experimental unit was calculated as the mean final $\mathrm{MeHg}$ burden minus the mean initial burden. Estimates of mayfly dry weights used in this calculation were predicted from regression of total length (millimetres) and dry weight (milligrams) of Hexagenia mayflies sampled during 1994 and 1995 in the Upper Mississippi River (log dry weight = $-2.666+2.849$ (log total length); $\left.r^{2}=0.80, n=633\right)$. A Type I error of 0.05 was used to judge the significance of all statistical tests.

\section{Results}

\section{Mercury in sediment, water, and mayflies}

Mean concentrations of $\Sigma \mathrm{Hg}$ in test sediments varied more than 100-fold among the six treatments in both test 1 and test 2 (Table 2). Mean concentrations in sediments ranged from 90 to $272 \mathrm{ng} \cdot \mathrm{g}$ dry weight ${ }^{-1}$ in the reference areas, from 880 to $1920 \mathrm{ng} \cdot \mathrm{g}^{-1}$ in the contaminated flowing reach and Fairhaven Bay, and from 7548 to $22059 \mathrm{ng} \cdot \mathrm{g}^{-1}$ in Reservoirs 1 and 2. In contrast, mean concentrations of $\mathrm{MeHg}$ in water at the end of tests 1 and 2 (all treatments) varied only 10-fold (Table 2). In general, concentrations of $\mathrm{MeHg}$ in test water were lowest in the reference flowing reach, intermediate in Fairhaven Bay, the contaminated flowing reach, and Reservoir 1, and highest in Reservoir 2.

Mayflies exposed to sediments from mercurycontaminated sites accumulated more $\mathrm{MeHg}$ than did mayflies exposed to reference sediments (Table 2). Concentrations of $\mathrm{MeHg}$ in mayflies exposed to sediments from the four contaminated areas were two (test 2) to three (test 1) times those in mayflies exposed to sediments from the two reference areas. In mayflies, the fraction of $\Sigma \mathrm{Hg}$ present as $\mathrm{MeHg}$ ranged from 1.2 to $28.5 \%$, with the highest percent $\mathrm{MeHg}$ occurring in mayflies exposed to sediment from the reference areas (Table 2).

In tests 3 and 4 , mean concentrations of $\Sigma \mathrm{Hg}$ in sediments varied about 10-fold among the four treatments, ranging from 186 to $261 \mathrm{ng} \cdot \mathrm{g}^{-1}$ in the reference wetland and from 1200 to $2562 \mathrm{ng} \cdot \mathrm{g}^{-1}$ in the two contaminated wetland areas and Fairhaven Bay (Table 2). MeHg concentrations in test water varied considerably among treatments at the end of tests 3 and 4 (Table 2). In both tests, waterborne concentrations of $\mathrm{MeHg}$ were much greater in treatments with contaminated wetland sediments $\left(8-47 \mathrm{ng} \mathrm{Hg} \cdot \mathrm{L}^{-1}\right)$ than in the treatment with reference wetland sediments $\left(0.9-2.1 \mathrm{ng} \mathrm{Hg} \cdot \mathrm{L}^{-1}\right)$.

Mean concentrations of $\mathrm{MeHg}$ in mayflies at the end of tests 3 and 4 ranged from 122 to $184 \mathrm{ng} \mathrm{Hg} \cdot \mathrm{g}^{-1}$ in treatments with contaminated wetland sediments, whereas concentrations in mayflies exposed to reference wetland sediments averaged about $36 \mathrm{ng} \mathrm{Hg} \cdot \mathrm{g}^{-1}$. The fraction of $\mathrm{\Sigma Hg}$ present as $\mathrm{MeHg}$ ranged from 11 to $41 \%$; the highest percentage was in mayflies exposed to sediments from the reference wetland (Table 2). Net $\mathrm{MeHg}$ accumulation was significantly greater in mayflies exposed to mercury-contaminated wetland sediments than in mayflies exposed to reference wetland sediment (Table 2).

When data from all four bioaccumulation tests were combined, there was a significant, positive correlation between the concentration of $\Sigma \mathrm{Hg}$ in mayflies and that in test sediment (Fig. 2). In general, concentrations of $\Sigma \mathrm{Hg}$ in mayflies were less than those in sediments. However, the net amount of $\mathrm{MeHg}$ accumulated in mayflies was not correlated with the concentration of $\mathrm{\Sigma Hg}$ in sediments (Spearman correlation, $r_{\mathrm{s}}=0.54, p=0.32$ ).

\section{Mayfly growth and survival}

The survival of Hexagenia in the four bioaccumulation tests was unrelated to the concentration of $\mathrm{\Sigma Hg}$ in test sediment. The overall survival of Hexagenia mayflies ranged from $90 \%$ in test 3 to $96 \%$ in test 2 . The mean survival of nymphs did not vary among treatments in any test $(p \geq 0.38$ in all tests).

The growth of Hexagenia during tests 1 and 2 varied significantly among sediment treatments but was unrelated to the mercury concentration in test sediment (Table 2). The mean growth of mayflies in the Whitehall Reservoir (reference) treatment was significantly less than that in four of the other five treatments in test 1 and less than that in all other 


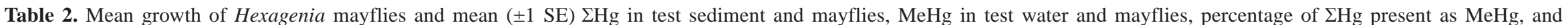
net $\mathrm{MeHg}$ accumulation in mayflies exposed to sediments from the Sudbury River basin in 21-day bioaccumulation tests.

\begin{tabular}{|c|c|c|c|c|c|c|c|}
\hline Treatment & $\begin{array}{l}\text { Growth of } \\
\text { mayflies }(\mathrm{mm})\end{array}$ & $\begin{array}{l}\Sigma \mathrm{Hg} \text { in sediment } \\
\left(\mathrm{ng} \cdot \mathrm{g} \text { dry weight }{ }^{-1}\right)\end{array}$ & $\begin{array}{l}\Sigma \mathrm{Hg} \text { in mayflies } \\
\left(\mathrm{ng} \cdot \mathrm{g} \text { dry weight }{ }^{-1}\right)\end{array}$ & $\begin{array}{l}\mathrm{MeHg} \text { in water } \\
\left(\mathrm{ng} \mathrm{Hg} \cdot \mathrm{L}^{-1}\right)\end{array}$ & $\begin{array}{l}\text { MeHg in mayflies } \\
\left(\text { ng Hg.g dry weight }^{-1}\right)\end{array}$ & $\begin{array}{l}\mathrm{MeHg} \text { as mean } \\
\text { percentage of } \Sigma \mathrm{Hg}\end{array}$ & $\begin{array}{l}\text { MeHg accumulation } \\
\left(\text { ng Hg } \cdot \text { mayfly }^{-1}\right)\end{array}$ \\
\hline \multicolumn{8}{|c|}{ Bioaccumulation test 1 (July 1994 sediments) } \\
\hline Whitehall Reservoir & $2.2 a$ & $149 \pm 19 a$ & $123 \pm 19 a$ & $1.68 \pm 0.51 a$ & $32.4 \pm 3.8 a$ & $27.3 \pm 2.0 a$ & $0.15 \pm 0.03 a$ \\
\hline Reference flowing reach & $6.2 c$ & $90 \pm 19 a$ & $149 \pm 13 a$ & $0.30 \pm 0.05 b$ & $41.0 \pm 5.8 a b$ & $28.5 \pm 4.5 a$ & $0.41 \pm 0.05 a b$ \\
\hline Reservoir 2 & $5.9 b c$ & $14780 \pm 4843 c$ & $6360 \pm 1448 c$ & $3.26 \pm 1.23 a$ & $117.8 \pm 40.3 c$ & $2.5 \pm 0.9 c$ & $1.38 \pm 0.53 c$ \\
\hline Reservoir 1 & $6.1 b c$ & $7548 \pm 694 c$ & $5182 \pm 1477 c$ & $1.12 \pm 0.30 a b$ & $84.1 \pm 19.4 b c$ & $1.9 \pm 0.4 c$ & $1.03 \pm 0.28 b c$ \\
\hline Contaminated flowing reach & $4.9 a b$ & $880 \pm 105 b$ & $759 \pm 194 b$ & $1.85 \pm 0.47 a$ & $105.4 \pm 40.7 b c$ & $13.1 \pm 2.8 b$ & $1.06 \pm 0.44 b c$ \\
\hline Fairhaven Bay & $5.3 b c$ & $1719 \pm 229 b$ & $874 \pm 162 b$ & $1.65 \pm 0.46 a$ & $127.1 \pm 27.1 c$ & $14.5 \pm 1.0 \mathrm{~b}$ & $1.39 \pm 0.36 c$ \\
\hline \multicolumn{8}{|c|}{ Bioaccumulation test 2 (September 1994 sediments) } \\
\hline Whitehall Reservoir & $2.3 a$ & $272 \pm 39 a$ & $171 \pm 16 a$ & $3.46 \pm 1.07 a$ & $39.0 \pm 4.1 a$ & $23.5 \pm 2.4 a$ & $0.14 \pm 0.03 a$ \\
\hline Reference flowing reach & $5.8 b$ & $200 \pm 39 a$ & $167 \pm 24 a$ & $0.75 \pm 0.15 b$ & $37.0 \pm 5.0 a$ & $24.3 \pm 4.6 a$ & $0.29 \pm 0.08 a$ \\
\hline Reservoir 2 & $5.8 b$ & $22059 \pm 4077 c$ & $10819 \pm 2282 c$ & $3.40 \pm 0.59 a$ & $93.0 \pm 9.1 b$ & $1.2 \pm 0.5 c$ & $0.92 \pm 0.07 b$ \\
\hline Reservoir 1 & $6.5 b$ & $11221 \pm 2279 c$ & $4147 \pm 814 c$ & $2.00 \pm 0.58 a b$ & $77.2 \pm 11.2 b$ & $2.4 \pm 0.7 c$ & $0.76 \pm 0.09 b$ \\
\hline Contaminated flowing reach & $6.3 b$ & $1920 \pm 216 b$ & $762 \pm 105 b$ & $1.21 \pm 0.38 a b$ & $75.0 \pm 13.4 b$ & $10.3 \pm 1.7 b$ & $0.79 \pm 0.15 b$ \\
\hline Fairhaven Bay & $6.2 b$ & $1775 \pm 375 b$ & $711 \pm 76 b$ & $1.75 \pm 0.58 a b$ & $82.5 \pm 3.9 b$ & $12.3 \pm 1.4 b$ & $0.89 \pm 0.07 b$ \\
\hline \multicolumn{8}{|c|}{ Bioaccumulation test 3 (May 1995 sediments) } \\
\hline Hop Brook wetland (reference) & $6.4 a$ & $261 \pm 27 a$ & $113 \pm 5 a$ & $0.93 \pm 0.08 a$ & $36.3 \pm 6.9 a$ & $33.0 \pm 7.0 a$ & $0.30 \pm 0.11 a$ \\
\hline Southern contaminated wetland & $6.0 a b$ & $2562 \pm 263 c$ & $1161 \pm 183 c$ & $8.34 \pm 1.62 d$ & $122.1 \pm 13.7 c$ & $11.2 \pm 0.9 b$ & $1.25 \pm 0.18 b$ \\
\hline Northern contaminated wetland & $4.8 b$ & $1275 \pm 123 b$ & $655 \pm 78 b$ & $14.92 \pm 1.70 c$ & $149.3 \pm 18.7 c$ & $24.1 \pm 2.7 a$ & $1.39 \pm 0.22 b$ \\
\hline Fairhaven Bay & $6.1 a b$ & $1791 \pm 308 b c$ & $833 \pm 147 b c$ & $0.58 \pm 0.07 b$ & $63.7 \pm 3.1 b$ & $12.5 \pm 4.3 b$ & $0.62 \pm 0.07 a$ \\
\hline \multicolumn{8}{|c|}{ Bioaccumulation test 4 (September 1995 sediments) } \\
\hline Hop Brook wetland (reference) & $4.0 a b$ & $186 \pm 24 a$ & $98 \pm 12 a$ & $2.05 \pm 0.70 a$ & $36.9 \pm 4.3 a$ & $40.6 \pm 5.0 a$ & $0.21 \pm 0.04 a$ \\
\hline Southern contaminated wetland & $2.8 b c$ & $1612 \pm 98 b$ & $515 \pm 28 b$ & $13.79 \pm 2.62 b$ & $138.0 \pm 16.9 b$ & $27.2 \pm 3.2 a$ & $0.91 \pm 0.16 b$ \\
\hline Northern contaminated wetland & $1.5 c$ & $1200 \pm 157 b$ & $539 \pm 70 b$ & $47.05 \pm 11.51 b$ & $183.7 \pm 25.0 \mathrm{~b}$ & $37.1 \pm 4.9 a$ & $0.91 \pm 0.16 b$ \\
\hline Fairhaven Bay & $5.7 a$ & $1429 \pm 339 b$ & $492 \pm 64 b$ & $0.96 \pm 0.12 a$ & $54.6 \pm 5.0 a$ & $12.2 \pm 1.4 b$ & $0.46 \pm 0.06 b$ \\
\hline
\end{tabular}

Note: Means for a given variable and test that are not accompanied by a common letter were significantly different (Tukey's HSD procedure, $\alpha=0.05$ ). Treatments (sediment source) for each test are listed in longitudinal sequence from upstream to downstream. 
Fig. 2. Relationship between $\Sigma \mathrm{Hg}$ concentration in Hexagenia mayflies and that in test sediments from all study sites in the Sudbury River basin (combined data from all four bioaccumulation tests).

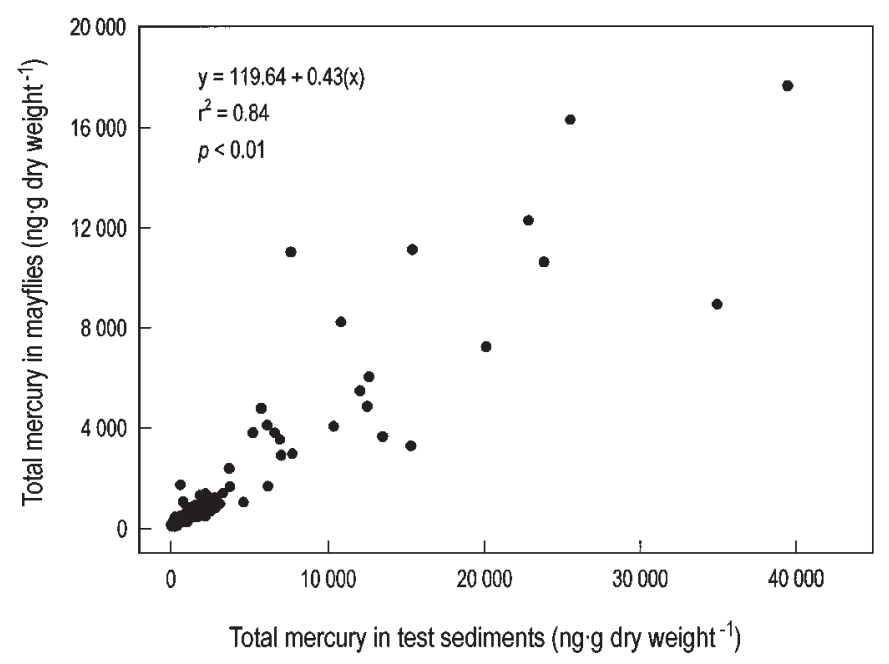

treatments in test 2 (Table 2). In tests 3 and 4, the growth of Hexagenia varied among treatments and between tests. In test 3, the mean growth of mayflies in the northern contaminated wetland treatment $(4.8 \mathrm{~mm})$ was significantly less than that in the reference wetland treatment (Table 2). In test 4 , the growth of mayflies averaged $1.5 \mathrm{~mm}$ for the northern contaminated wetland, $2.8 \mathrm{~mm}$ for the southern contaminated wetland, $4.0 \mathrm{~mm}$ for the reference wetland, and $5.7 \mathrm{~mm}$ for Fairhaven Bay (Table 2). The overall mean growth of mayflies (all treatments combined) was greater in test $3(5.8 \mathrm{~mm})$ than in test $4(3.5 \mathrm{~mm})$. Variation in the growth of mayfly nymphs was seemingly unrelated to mercury exposure, given that growth did not diminish with increasing concentrations of $\mathrm{MeHg}$ in test water, $\Sigma \mathrm{Hg}$ in sediment, $\Sigma \mathrm{Hg}$ in mayflies, or MeHg in mayflies (Fig. 3).

\section{Discussion}

The concentrations of $\Sigma \mathrm{Hg}$ in our test sediments far exceeded the estimated natural abundance of 40-50 ng.g dry weight $^{-1}$ (Frazier et al. 2000), confirming substantial mercury contamination throughout the studied $34-\mathrm{km}$ reach of the Sudbury River. Test sediments from the three reference areas had mercury concentrations ranging from two to five times the estimated natural abundance, indicating the presence of anthropogenic mercury throughout the basin. Concentrations of $\Sigma \mathrm{Hg}$ in surficial sediments diminished, as expected, with increasing distance downstream from the Nyanza site (Fig. 4). The greatest concentrations of $\Sigma \mathrm{Hg}$ in sediments in this study were in Reservoir 2 , about $3 \mathrm{~km}$ downstream from the Nyanza site. In sediments taken 25$35 \mathrm{~km}$ downstream from the Nyanza site, the concentration of mercury was roughly 10 -fold higher than concentrations in the reference flowing reach, upstream of the Nyanza site.

The growth of mayflies was unrelated to the $\mathrm{\Sigma Hg}$ concentration in sediment. The slower growth of Hexagenia exposed to sediments from Whitehall Reservoir (tests 1 and 2) may have resulted from the physical characteristics of sediment, given that Whitehall Reservoir sediments contained more volatile matter than other sediments (Table 1). Mayflies exposed to wetland sediment grew less in test 4 than in test 3, probably because of differences in test conditions related to water levels in the wetlands when test sediments were obtained. Wetland sediments for test 3 were obtained from an inundated floodplain, whereas wetland sediments for test 4 were not inundated, due to severe drought conditions in the basin during the summer of 1995. Growth was slowest in mayflies exposed to sediments taken from the northern contaminated wetland in September 1995; this treatment had the highest $\mathrm{MeHg}$ concentration and the lowest $\mathrm{pH}$ (mean 5.9) in test water. This $\mathrm{pH}$ value is near the $\mathrm{pH}$ threshold of 5.2-5.5 suggested by McNicol et al. (1995) as the $\mathrm{pH}$ below which recolonization of lake sediments by acid-sensitive invertebrate taxa is unlikely. We suspect that the lower $\mathrm{pH}$ of our test waters in wetland treatments in test 4 , relative to test 3 , resulted from the release of hydrogen ion during oxidation of sulfide in the air-exposed wetland sediment (Yan et al. 1996; Anisfeld and Benoit 1997). In contrast with the wetland areas studied, sediments from Fairhaven Bay were inundated during sampling for tests 3 and 4, and the growth of mayflies in the Fairhaven Bay treatment did not differ between the two tests.

The concentration of $\Sigma \mathrm{Hg}$ was not a reliable indicator of $\mathrm{MeHg}$ concentration in mayflies in our study. Neither the concentration nor the burden of $\mathrm{MeHg}$ accumulated by mayflies was correlated with the concentration of $\Sigma \mathrm{Hg}$ in the sediment to which they were exposed. In addition, the fraction of $\mathrm{\Sigma Hg}$ present as $\mathrm{MeHg}$ in exposed mayflies was highly variable, ranging from 1 to $41 \%$ in our tests. The $\mathrm{MeHg}$ to $\Sigma \mathrm{Hg}$ ratio in mayflies was greatest in nymphs exposed to reference sediments and lowest in nymphs exposed to the most contaminated sediments. These observations reinforce the importance of measuring $\mathrm{MeHg}$ in benthic macroinvertebrates such as aquatic insects (Hall et al. 1998). In our study, no inferences on $\mathrm{MeHg}$ contamination of sedimentdwelling mayflies could be made from information on concentrations of $\mathrm{\Sigma Hg}$ in either sediment or mayflies.

The whole-body content of metals in benthic insects can be influenced by ingested materials, such as sediment particles, in the gut (Hare et al. 1989; Cain et al. 1995). We estimated the potential contribution of gut contents to the whole-body burdens of $\mathrm{\Sigma Hg}$ and $\mathrm{MeHg}$ accumulated by mayfly nymphs in our tests by assuming that the gut of a Hexagenia contained $1.2 \mathrm{mg}$ dry weight of ingested sediment, a value derived for individual Hexagenia rigida by Odin et al. (1997). In mayflies exposed to sediments from contaminated reaches, we estimated that from 13 to $52 \%$ of the $\Sigma \mathrm{Hg}$ in the whole mayfly was contributed by gut contents, with the remainder of the whole-body burden contributed by bioaccumulation and adsorption. In mayflies exposed to reference sediments, we estimate that from 6 to $28 \%$ of the $\Sigma \mathrm{Hg}$ in the body was contributed by ingested sediment in the gut. To assess the potential contribution of ingested sediment to MeHg burdens in mayflies, we used data from Colman et al. (1999) on maximum concentrations of $\mathrm{MeHg}$ in surficial sediments from contaminated palustrine wetlands along the Sudbury River. The gut of an individual mayfly would have contained an estimated maximum of $0.02 \mathrm{ng}$ of mercury present as $\mathrm{MeHg}$. During our tests, individual mayflies exposed to contaminated wetland sediments 
Fig. 3. Growth of Hexagenia mayfly nymphs during all four 21-day bioaccumulation tests with sediments from the Sudbury River basin, with the increase in total length plotted against (a) MeHg in test water, (b) $\Sigma \mathrm{Hg}$ in test sediments, (c) $\Sigma \mathrm{Hg}$ in mayflies, and (d) $\mathrm{MeHg}$ in mayflies.
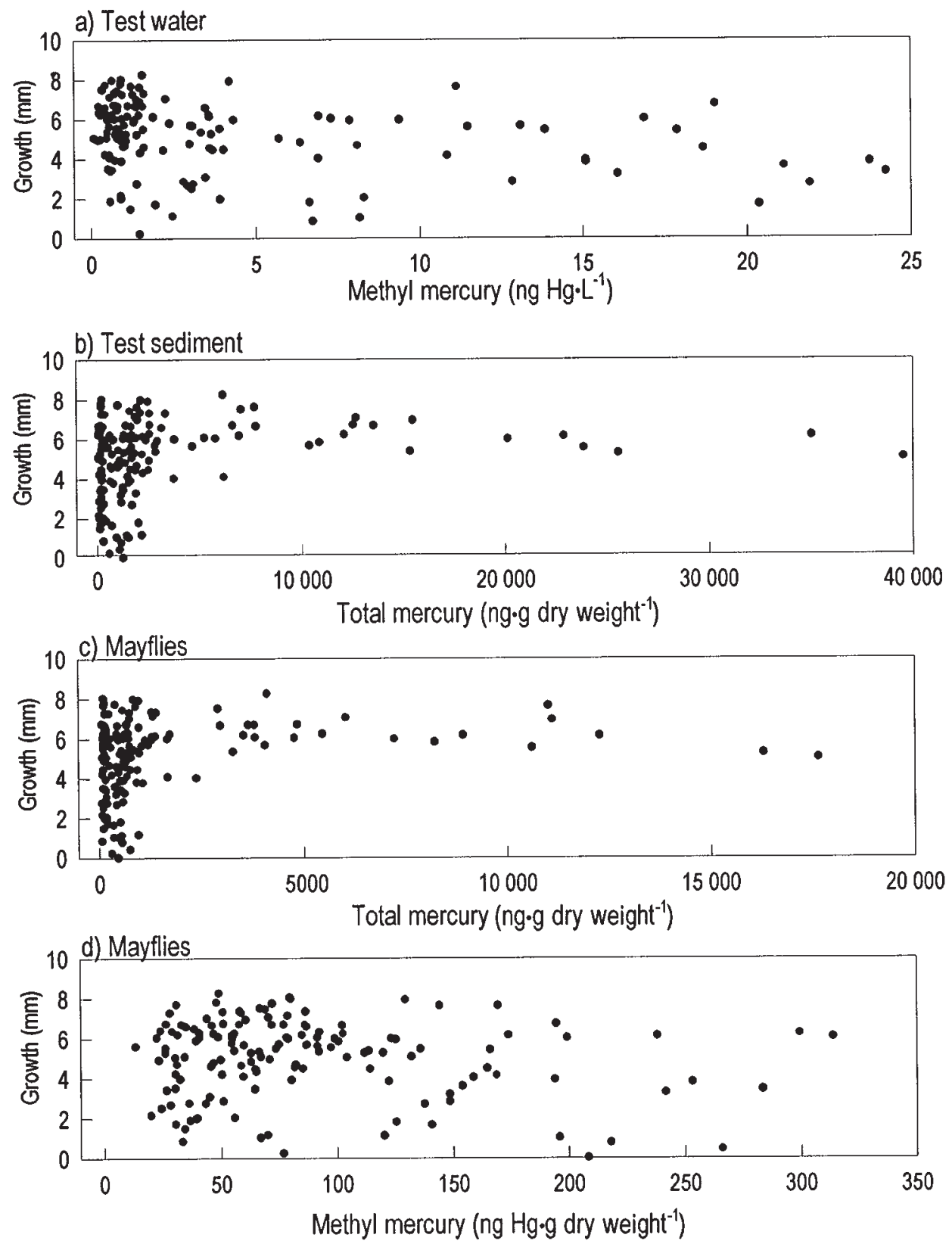

accumulated between 0.91 and 1.39 ng of mercury as $\mathrm{MeHg}$. Our admittedly crude calculations indicate that very little, at most perhaps $2 \%$, of the $\mathrm{MeHg}$ in the whole body was contributed by $\mathrm{MeHg}$ in ingested sediment present in the gut.

Comparison of $\mathrm{MeHg}$ in test water and mayflies with $\Sigma \mathrm{Hg}$ in test sediments from the two highly contaminated reservoirs indicated that very little $\mathrm{MeHg}$ was produced from the large sedimentary inventories of inorganic mercury at these sites (Fig. 5). In contrast, our tests clearly showed that $\mathrm{MeHg}$, the form readily accumulated in fish and biomagnified in aquatic food chains (Bloom 1992; Wiener and Spry 1996), was actively produced in surficial sediments from the lesser contaminated wetlands (Fig. 5). Moreover, this $\mathrm{MeHg}$ was available for uptake by detritus-feeding benthic organ- isms in the riverine food web. Colman et al. (1999), who analyzed sediment cores from wetlands on the Sudbury River floodplain, found that $\mathrm{MeHg}$ concentrations in both bulk sediment and pore water were greatest in the uppermost stratum of each core. Within this upper stratum, concentrations of $\mathrm{MeHg}$ ranged from about 6 to $22 \mathrm{ng} \mathrm{Hg} \cdot \mathrm{g}$ dry weight ${ }^{-1}$ in bulk sediments (six cores) and from about 4.5 to $7.1 \mathrm{ng}$ $\mathrm{Hg} \cdot \mathrm{L}^{-1}$ in pore water (three cores). Moreover, $\mathrm{MeHg}$ was present in the wetland sediments throughout the summer, even when floodplain sediments were exposed to the atmosphere (Colman et al. 1999).

Our results showing the importance of wetland sediments as active sites of $\mathrm{MeHg}$ production agree with the results of Waldron et al. (2000), who examined spatial trends in the 
Fig. 4. $\Sigma \mathrm{Hg}$ in test sediments (solid circles) and $\mathrm{MeHg}$ in Hexagenia mayflies (open circles) as a function of distance downstream from the Nyanza site (combined data from all four bioaccumulation tests). Approximate downstream distances from the Nyanza site were as follows: Reservoir 2, $4 \mathrm{~km}$; Reservoir 1, $6 \mathrm{~km}$; contaminated flowing reach and contaminated wetland reaches, 25-31 km; Fairhaven Bay, $34 \mathrm{~km}$. The three reference areas (Whitehall Reservoir, reference flowing reach, and Hop Brook wetland) were plotted as negative distance because all are upstream from or uninfluenced by the Nyanza site.

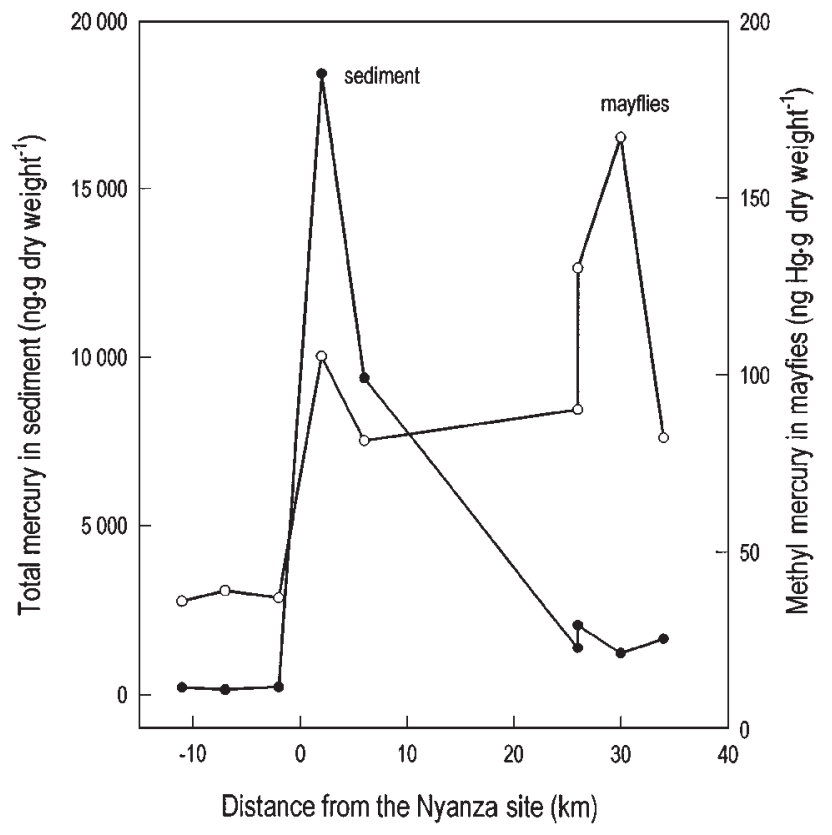

abundances of $\mathrm{MeHg}$ and $\mathrm{\Sigma Hg}$ in water from the Sudbury River. $\mathrm{MeHg}$ production in wetlands has also been documented elsewhere, including boreal forest ecosystems in Canada (St. Louis et al. 1994, 1996; Kelly et al. 1997) and several watersheds in Wisconsin (Hurley et al. 1995; Krabbenhoft et al. 1995). St. Louis et al. (1994), for example, reported that $\mathrm{MeHg}$ yields from wetlands were 26-79 times greater than yields from purely upland catchment areas. In subsequent work, St. Louis et al. (1996) documented that different types of wetlands (i.e., headwater wetlands, riverine wetlands, valley-bottom wetlands) can function as sources or sinks of $\mathrm{MeHg}$ and $\mathrm{\Sigma Hg}$ to downstream reaches, depending on the percent wetland in a given catchment and the annual water yield. Furthermore, yields of $\mathrm{MeHg}$ from wetland areas can greatly exceed the inputs of $\mathrm{MeHg}$ in atmospheric deposition (Krabbenhoft et al. 1995).

The net production of $\mathrm{MeHg}$ in our treatments with wetland sediments may have been enhanced partly by low $\mathrm{pH}$. Several studies have shown that the net rate of microbial production of $\mathrm{MeHg}$ (i.e., methylation minus demethylation) in aquatic ecosystems increases in response to acidification or lowered pH (Xun et al. 1987; Gilmour et al. 1992). The northern contaminated wetland treatment had the lowest mean $\mathrm{pH}$ and the highest mean $\mathrm{MeHg}$ in water $\left(15 \mathrm{ng} \mathrm{Hg} \cdot \mathrm{L}^{-1}\right.$ at $\mathrm{pH} 6.6$ in test 3 and $47 \mathrm{ng} \mathrm{Hg} \cdot \mathrm{L}^{-1}$ at $\mathrm{pH} 5.9$ in test 4) measured in the present study. Moreover, mean concentrations of $\mathrm{MeHg}$ in water in the three treatments with wetland
Fig. 5. Concentrations of $\mathrm{MeHg}$ in (a) test water (note the discontinuous scale on the vertical axis) and (b) Hexagenia mayflies, plotted against $\Sigma \mathrm{Hg}$ in test sediments from habitats in the Sudbury River basin (combined data from all four bioaccumulation tests).
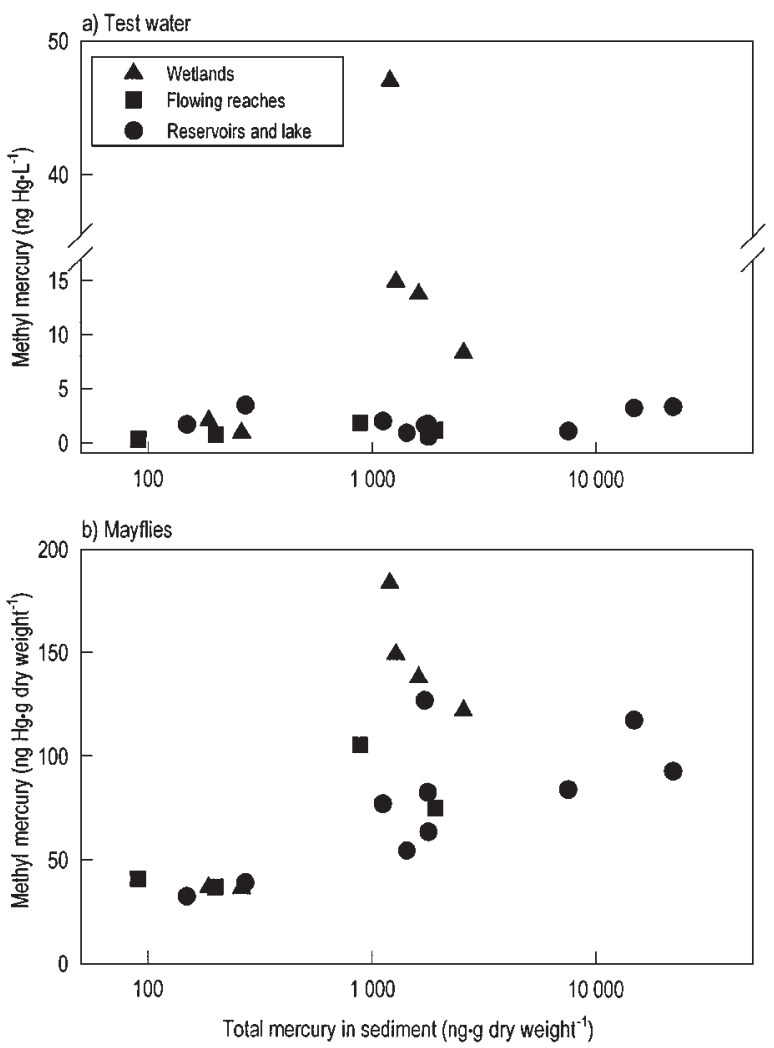

sediments were higher in test 4 , which had lower $\mathrm{pH}$ in test water, than in test 3 .

Viewed longitudinally, the patterns of $\mathrm{MeHg}$ in sedimentexposed mayflies and in river water (Waldron et al. 2000) clearly did not correspond to the spatial gradient in $\Sigma \mathrm{Hg}$ concentration in the surficial sediments (Fig. 4). MeHg concentrations peaked about 3-5 $\mathrm{km}$ downstream from the Nyanza site, leveled off between 5 and $25 \mathrm{~km}$ downstream from the Nyanza site, and peaked again in the contaminated wetland reaches (Fig. 4). Moreover, the spatial trend in $\mathrm{MeHg}$ concentrations in mayflies paralleled the spatial trend in abundance of $\mathrm{MeHg}$ in water from the river (Waldron et al. 2000). In their field study, Waldron et al. (2000) found that $\mathrm{MeHg}$ concentrations in unfiltered river water were highest in the reach just downstream from the Nyanza site (0.19-0.29 $\left.\mathrm{ng} \mathrm{Hg} \cdot \mathrm{L}^{-1}\right)$, substantially lower at sampling points between 5 and $25 \mathrm{~km}$ downstream from the Nyanza site $\left(0.11-0.15 \mathrm{ng} \mathrm{Hg} \cdot \mathrm{L}^{-1}\right)$, and higher in the wetland reaches $\left(0.19-0.23 \mathrm{ng} \mathrm{Hg} \cdot \mathrm{L}^{-1}\right)$.

Fish in natural waters obtain $\mathrm{MeHg}$ almost entirely through the diet (Rodgers 1994; Wiener and Spry 1996; Hall et al. 1997). Our estimates of net $\mathrm{MeHg}$ accumulation in individual mayfly nymphs consequently provide a relevant index of the potential transfer (flux) of $\mathrm{MeHg}$ from the sediments into aquatic food webs. Mayflies accumulated between 0.14 and $1.4 \mathrm{ng}$ of mercury (as $\mathrm{MeHg}$ ) per nymph during our 21-day bioaccumulation tests. Nymphs exposed 
to mercury-contaminated sediments usually accumulated considerably more $\mathrm{MeHg}$ than those exposed to reference sediments. The potential significance of the mercurycontaminated wetland areas as sources of $\mathrm{MeHg}$ in this ecosystem is increased by the tendency of wetland habitats to export waterborne $\mathrm{MeHg}$ to adjoining surface waters (Hurley et al. 1995; St. Louis et al. 1996; Waldron et al. 2000).

In conclusion, mayfly nymphs accumulated significant quantities of $\mathrm{MeHg}$ during 21-day exposures to contaminated sediments from the Sudbury River. Mercurycontaminated, surficial sediments from impoundments, flowing reaches, and palustrine wetlands in the basin were not toxic to burrowing mayflies, and the growth of mayflies was unrelated to the concentration of $\mathrm{\Sigma Hg}$ in sediments. Concentrations of $\mathrm{MeHg}$ were greatest in mayflies and test water exposed to sediment from contaminated wetland areas about $30 \mathrm{~km}$ or more downstream from the Nyanza site. The production of $\mathrm{MeHg}$ and its potential entry into the benthic food web in this ecosystem were greater in the contaminated floodplain wetlands than in the more heavily contaminated reservoirs nearer the Nyanza site.

\section{Acknowledgments}

This work was funded by the U.S. Environmental Protection Agency (Region I) through an interagency agreement with the U.S. Fish and Wildlife Service (Region V). We thank the staff of the Great Meadows National Wildlife Refuge for use of their facility during sampling trips. The assistance of Pamela Shields (U.S. Environmental Protection Agency), Susan Svirsky (U.S. Environmental Protection Agency), and Steven Mierzykowski (U.S. Fish and Wildlife Service) during planning of the study is gratefully acknowledged. Assistance in the field and (or) laboratory was provided by Lori Bliss, Erika Damschen, Martin Deters, Bradley Frazier, Michael Oetker, Peter Rust, and Kimberly Skroch. We thank John Besser, Britt Hall, James Hurley, Efrosini Tsalkitzis, and two anonymous reviewers for helpful comments on earlier drafts of the manuscript.

\section{References}

American Society for Testing and Materials. 1992. Annual book of ASTM standards. Vol. 11.04. Water and environmental technology. Standard Guide E 1391-90. Collection, storage, characterization, and manipulation of sediments for toxicological testing. American Society for Testing and Materials, Philadelphia, Pa.

Anisfeld, S.C., and Benoit, G. 1997. Impacts of flow restrictions on salt marshes: an instance of acidification. Environ. Sci. Technol. 31: $1650-1657$.

Beauvais, S.L., Wiener, J.G., and Atchison, G.J. 1995. Cadmium and mercury in sediment and burrowing mayfly nymphs (Hexagenia) in the Upper Mississippi River, U.S.A. Arch. Environ. Contam. Toxicol. 28: 178-183.

Bloom, N.S. 1989. Determination of picrogram levels of methylmercury by aqueous phase ethylation, followed by cryogenic gas chromatography with cold vapour atomic fluorescence detection. Can. J. Fish. Aquat. Sci. 46: 1131-1140.

Bloom, N.S. 1992. On the chemical form of mercury in edible fish and marine invertebrate tissue. Can. J. Fish. Aquat. Sci. 49: 1010-1017.
Bloom, N.S., and Crecelius, E.A. 1983. Determination of mercury in seawater at sub-nanogram per liter levels. Mar. Chem. 14: 49-59.

Bloom, N.S., and Crecelius, E.A. 1987. Distribution of silver, mercury, lead, copper, and cadmium in central Puget Sound sediments. Mar. Chem. 21: 377-390.

Bloom, N.S., and Fitzgerald, W.F. 1988. Determination of volatile mercury species at the picogram level by low temperature gas chromatography with cold vapor atomic fluorescence detection. Anal. Chim. Acta, 208: 151-161.

Bloom, N.S., and Von Der Geest, E.J. 1995. Matrix modification to improve the recovery of $\mathrm{MMHg}$ from clear water using distillation. Water Air Soil Pollut. 80: 1319-1323.

Cain, D.J., Luoma, S.N., and Axtmann, E.V. 1995. Influence of gut content in immature aquatic insects on assessments of environmental metal contamination. Can. J. Fish. Aquat. Sci. 52: 2736-2746.

Colman, J.A., Waldron, M.C., Breault, R.F., and Lent, R.M. 1999. Distribution and transport of total mercury and methylmercury in mercury-contaminated sediments in reservoirs and wetlands of the Sudbury River, east-central Massachusetts. U.S. Geol. Surv. Water-Resour. Invest. Rep. 99-4060.

Fitzgerald, W.F., Mason, R.P., and Vandal, G.M. 1991. Atmospheric cycling and air-water exchange of mercury over mid-continental lacustrine regions. Water Air Soil Pollut. 56: 745-767.

Frazier, B.E., Wiener, J.G., Rada, R.G., and Engstrom, D.R. 2000. Stratigraphy and historic accumulation of mercury in recent depositional sediments in the Sudbury River, Massachusetts, U.S.A. Can. J. Fish. Aquat. Sci. 57: 1062-1072.

Gilmour, C.C., Henry, E.A., and Mitchell, R. 1992. Sulfate stimulation of mercury methylation in freshwater sediments. Environ. Sci. Technol. 26: 2281-2287.

Guy, H.P. 1969. Laboratory theory and methods for sediment analysis. Techniques of water resources investigations. Book 5, Chap. C1. U.S. Geological Survey, Washington, D.C.

Hall, B.D., Bodaly, R.A., Fudge, R.J.P., Rudd, J.W.M., and Rosenberg, D.M. 1997. Food as the dominant pathway of methylmercury uptake by fish. Water Air Soil Pollut. 100: 13-24.

Hall, B.D., Rosenberg, D.M., and Wiens, A.P. 1998. Methyl mercury in aquatic insects from an experimental reservoir. Can. J. Fish. Aquat. Sci. 55: 2036-2047.

Hare, L., Campbell, P.G.C., Tessier, A., and Belzile, N. 1989. Gut sediments in a burrowing mayfly (Ephemeroptera, Hexagenia limbata): their contribution to animal trace element burdens, their removal, and the efficacy of a correction for their presence. Can. J. Fish. Aquat. Sci. 46: 451-456.

Harris, S.L. 1996. Massachusetts wetland resources. In National water summary on wetland resources. U.S. Geol. Surv. WaterSupply Pap. 2425. pp. 225-230.

Horvat, M., Liang, L., and Bloom, N.S. 1993. Comparison of distillation with other current isolation methods for the determination of methyl mercury-compounds in low-level environmental samples. 2. Water. Anal. Chim. Acta, 282: 153-168.

Hurley, J.P., Benoit, J.M., Babiarz, C.L., Shafer, M.M., Andren, A.W., Sullivan, J.R., Hammond, R., and Webb, D.A. 1995. Influences of watershed characteristics on mercury levels in Wisconsin rivers. Environ. Sci. Technol. 29: 1867-1875.

Kelly, C.A., Rudd, J.W.M., Bodaly, R.A., Roulet, N.P., St. Louis, V.L., Heyes, A., Moore, T.R., Schiff, S., Aravena, R., Scott, K.J., Dyck, B., Harris, R., Warner, B., and Edwards, G. 1997. Increases in fluxes of greenhouse gases and methyl mercury following flooding of an experimental reservoir. Environ. Sci. Technol. 31: 1334-1344.

Krabbenhoft, D.P., Benoit, J.M., Babiarz, C.L., Hurley, J.P., and Andren, A.W. 1995. Mercury cycling in the Allequash Creek watershed, northern Wisconsin. Water Air Soil Pollut. 80: 425-433. 
Liang, L., Bloom, N.S., and Horvat, M. 1994. Simultaneous determination of mercury speciation in biological materials by GC/CVAFS after ethylation and room temperature precollection. Clin. Chem. 40: 602-607.

McNicol, D.K., Bendell, B.E., and Mallory, M.L. 1995. Evaluating macroinvertebrate responses to recovery from acidification in small lakes in Ontario, Canada. Water Air Soil Pollut. 85: 451-456.

NUS Corporation. 1992. Final remedial investigation report. Nyanza Operable Unit III, Sudbury River study, Middlesex County, Massachusetts. Vol. 1. NUS Rep. W92194F. NUS Corporation, Wilmington, Mass.

Odin, M., Feurtet-Mazel, A., Ribeyre, F., and Boudou, A. 1994. Actions and interactions of temperature, $\mathrm{pH}$, and photoperiod on mercury bioaccumulation by nymphs of the burrowing mayfly Hexagenia rigida, from the sediment contamination source. Environ. Toxicol. Chem. 13: 1291-1302.

Odin, M., Ribeyre, F., and Boudou, A. 1995. Cadmium and methylmercury bioaccumulation by nymphs of the burrowing mayfly Hexagenia rigida from the water column and sediment. Environ. Sci. Pollut. Res. 2: 145-152.

Odin, M., Ribeyre, F., and Boudou, A. 1997. Depuration processes after exposure of burrowing mayfly nymphs (Hexagenia rigida) to methylmercury and cadmium from water column or sediment: effects of temperature and pH. Aquat. Toxicol. 37: 125-137.

Plumb, R.H., Jr. 1981. Procedures for handling and chemical analysis of sediment and water samples. Tech. Rep. EPA/CE-81-1. U.S. Environmental Protection Agency and U.S. Army Corps of Engineers, Technical Committee on Criteria for Dredged and Fill Material, Vicksburg, Miss.

Ramlal, P.S., Kelly, C.A., Rudd, J.W.M., and Furutani, A. 1993. Sites of methyl mercury production in remote Canadian Shield lakes. Can. J. Fish. Aquat. Sci. 50: 972-979.

Rodgers, D.W. 1994. You are what you eat and a little bit more: bioenergetics-based models of methylmercury accumulation in fish revisited. In Mercury pollution: integration and synthesis. Edited by C.J. Watras and J.W. Huckabee. Lewis Publishers, Boca Raton, Fla. pp. 427-439.

Rudd, J.W.M. 1995. Sources of methyl mercury to freshwater ecosystems: a review. Water Air Soil Pollut. 80: 697-713.
Saouter, E., Ribeyre, F., Boudou, A., and Maury-Brachet, R. 1991. Hexagenia rigida (Ephemeroptera) as a biological model in aquatic ecotoxicology: experimental studies on mercury transfers from sediment. Environ. Pollut. 69: 51-67.

Saouter, E., Hare, L., Campbell, P.G.C., Boudou, A., and Ribeyre, F. 1993. Mercury accumulation in the burrowing mayfly Hexagenia rigida (Ephemeroptera) exposed to $\mathrm{CH}_{3} \mathrm{HgCl}$ or $\mathrm{HgCl}_{2}$ in water and sediment. Water Res. 27: 1041-1048.

St. Louis, V.L., Rudd, J.W.M., Kelly, C.A., Beaty, K.G., Bloom, N.S., and Flett, R.J. 1994. Importance of wetlands as sources of methyl mercury to boreal forest ecosystems. Can. J. Fish. Aquat. Sci. 51: 1065-1076.

St. Louis, V.L., Rudd, J.W.M., Kelly, C.A., Beaty, K.G., Flett, R.J., and Roulet, N.T. 1996. Production and loss of methylmercury and loss of total mercury from boreal forest catchments containing different types of wetlands. Environ. Sci. Technol. 30: 2719-2729.

Waldron, M.C., Colman, J.A., and Breault, R.F. 2000. Distribution, hydrologic transport, and cycling of total mercury and methyl mercury in a contaminated river-reservoir-wetland system (Sudbury River, eastern Massachusetts). Can. J. Fish. Aquat. Sci. 57: 1080-1091.

Wiener, J.G., and Shields, P.J. 2000. Mercury in the Sudbury River (Massachusetts, U.S.A.): pollution history and a synthesis of recent research. Can. J. Fish. Aquat. Sci. 57: 1053-1061.

Wiener, J.G., and Spry, D.J. 1996. Toxicological significance of mercury in freshwater fish. In Environmental contaminants in wildlife: interpreting tissue concentrations. Edited by W.N. Beyer, G.H. Heinz, and A.W. Redmon-Norwood. Special Publication of the Society of Environmental Toxicology and Chemistry. Lewis Publishers, Boca Raton, Fla. pp. 297-339.

Xun, L., Campbell, N.E.R., and Rudd, J.W.M. 1987. Measurements of specific rates of net methyl mercury production in the water column and surface sediments of acidified and circumneutral lakes. Can. J. Fish. Aquat. Sci. 44: 750-757.

Yan, N.D., Keller, W., Scully, N.M., Lean, D.R.S., and Dillon, P.J. 1996. Increased UV-B penetration in a lake owing to droughtinduced acidification. Nature (Lond.), 381: 141-143. 